\title{
PERBANDINGAN PBL DAN DL TERHADAP PEMAHAMAN KONSEPTUAL SISWA KELAS XI DITINJAU DARI MOTIVASI BELAJAR
}

\author{
Yunia Eka Putri ${ }^{1}$, Erlina Prihatnani ${ }^{2}$ \\ ${ }^{1,2}$ Pendidikan Matematika Universitas Kristen Satya Wacana, Jalan Diponegoro No.52-60 Salatiga \\ 202016064@student.uksw.edu
}

\begin{abstract}
This study aims to compare PBL and DL models against students' conceptual understanding in terms of learning motivation. Data were analyzed using non-parametric tests. The results showed that: (1) the conceptual understanding of students subjected to DL produced a conceptual understanding that was significantly better than PBL; (2) there is a significant difference in conceptual understanding from the three levels of learning motivation, students with high learning motivation significantly produce better conceptual understanding than students with moderate and low learning motivation, while students with moderate learning motivation significantly produce more conceptual understanding better than students with low learning motivation; (3) there is an interaction between PBL learning models with learning motivation towards students' conceptual understanding, namely the high level of learning motivation significantly results in a better conceptual understanding than moderate and low motivation levels, whereas moderate learning motivation significantly results in a better conceptual understanding than students with low learning motivation, while in the DL learning model the conceptual understanding produced by students with high, medium and low motivation levels is the same, at the level of high and medium learning motivation there is no significant difference between PBL and DL models, whereas students with low motivation levels at DL classes significantly gain a better conceptual understanding than students with low motivation levels in PBL classes.
\end{abstract}

Keywords: DL, learning motivation, PBL, conceptual understanding

\begin{abstract}
Abstrak
Penelitian ini bertujuan untuk membandingkan model PBL dan DL terhadap pemahaman konseptual siswa ditinjau dari motivasi belajar. Data dianalisis menggunakan uji non-parametik. Hasil penelitian menunjukkan bahwa: (1) pemahaman konseptual siswa yang dikenai DL menghasilkan pemahaman konseptual yang secara signifikan lebih baik dibandingkan PBL; (2) terdapat perbedaan pemahaman konseptual yang signifikan dari ketiga tingkat motivasi belajar, siswa dengan motivasi belajar tinggi seecara signifikan menghasilkan pemahaman konseptual yang lebih baik dibanding siswa dengan motivasi belajar sedang dan rendah, sedangkan siswa dengan motivasi belajar sedang secara signifikan menghasilkan pemahaman konseptual yang lebih baik dibanding siswa dengan motivasi belajar rendah; (3) terdapat interaksi antara model pembelajaran PBL dengan motivasi belajar terhadap pemahaman konseptual siswa yaitu tingkat motivasi belajar tinggi secara signifikan menghasilkan pemahaman konseptual yang lebih baik dari pada tingkat motivasi sedang dan rendah sedangkan motivasi belajar sedang secara signifikan menghasilkan pemahaman konseptual yang lebih baik dibanding siswa dengan motivasi belajar rendah, adapun pada model pembelajaran DL pemahaman konseptual yang dihasilkan siswa dengan tingkat motivasi tinggi, sedang dan rendah sama, pada tingkat motivasi belajar tinggi dan sedang tidak terdapat perbedaan yang signifikan antara model PBL dan DL, sedangkan siswa dengan tingkat motivasi rendah pada kelas DL secara signifikan mendapatkan pemahaman konseptual yang lebih baik dari pada siswa dengan tingkat motivasi rendah pada kelas PBL.
\end{abstract}

Kata kunci: DL, motivasi belajar, PBL, pemahaman konseptual

\section{PENDAHULUAN}

Pendidikan merupakan suatu kegiatan mempersiapkan peserta didik melalui pengajaran, bimbingan dan latihan sebagai bekal untuk peserta didik di masa depan (UU Sisdiknas No 20/2003). Salah satu mata pelajaran di sekolah yang dapat digunakan untuk mencapai tujuan pendidikan adalah Matematika. Bruner dalam Suherman, dkk (2003: 43) menyatakan bahwa belajar matematika akan lebih berhasil jika proses pembelajaran diarahkan pada konsep dan struktur dalam pokok bahasan yang sedang diajarkan. Visi dari pembelajaran matematika adalah memenuhi kebutuhan masa kini melalui pembelajaran yang diarahkan kepada pemahaman konsep. 
Pemahaman konsep tersusun dari kata "pemahaman" dan "konsep". Menurut Sardiman (2008: 42), pemahaman dapat diartikan penguasaan sesuatu menggunakan pikiran. Rusman (2010: 139) menyatakan bahwa pemahaman adalah suatu proses individu dalam menerima dan juga memahami informasi yang ia peroleh dari pembelajaran yang ia dapat. Berdasarkan pengertian kata pemahaman dan konsep, maka pemahaman konsep adalah proses individu dalam menerima, memahami, dan menguasai suatu ide abstrak yang mewakili sejumlah objek dengan ciri-ciri sama yang diperoleh dari pembelajaran. Menurut Soedjadi (2000: 14), konsep merupakan ide abstrak yang dapat digunakan untuk menggolongkan atau mengklasifikasikan sekumpulan obyek.

Menurut Permendikbud Nomor 58 Tahun 2014, terdapat delapan indikator pemahaman konsep matematis yaitu sebagai berikut: 1) Menyatakan ulang konsep yang telah dipelajari. 2) Mengklasifikasi objek-objek berdasarkan dipenuhi tidaknya persyaratan yang membentuk konsep tersebut. 3) Mengidentifikasi sifat-sifat operasi atau konsep. 4) Menerapkan konsep secara logis. 5) Memberikan contoh atau contoh kontra. 6) Menyajikan konsep dalam berbagai macam bentuk representasi matematis. 7) Mengaitkan berbagai konsep dalam matematika maupun diluar matematika. 8) Mengembangkan syarat perlu dan syarat cukup suatu konsep.

Faktor yang mempengaruhi proses belajar untuk mencapai pemahaman konsep adalah faktor internal dan faktor eksternal. Faktor internal meliputi karakter siswa, sikap terhadap belajar, motivasi belajar, konsentrasi belajar, mengolah bahan belajar, menggali hasil belajar, rasa percaya diri, dan kebiasaan belajar serta faktor model pembelajaran yang digunakan guru (Aunurrahman, 2012).

Kualitas pendidikan matematika dapat dilihat pada data survei Trends in International Mathematics and Science Studi (TIMSS) di mana Indonesia menempati peringkat 45 dari 50 negara pada tahun 2015 (Kemendikbud, 2015). Rendahnya penilaian dari TIMSS adalah suatu akibat dari rendahnya kemampuan siswa dalam pemecahan masalah matematika.

Salah satu penyebab rendahnya pemahaman konsep menurut Lynch dan Waters dalam Suarman (2007) adalah siswa sering belajar dengan cara mengahafal tanpa memahami betul pengertian terhadap materi yang sedang dipelajari. Hal ini menyebabkan rendahnya aktivitas siswa dalam belajar untuk menemukan sendiri konsep materi yang dipelajari sehingga akan lebih cepat lupa. Oleh karena itu, diperlukan pembelajaran yang mendukung untuk mengembangkan pemahaman konsep siswadengan baik.

Menurut penelitian yang telah dilakukan oleh Suriana dkk (2016), model Problem Based Learning (PBL) dapat meningkatkan pemahaman konseptual siswa. Melalui penerapan PBL, pemahaman konseptual siswa kelas eksperimen lebih tinggi disbanding kelas kontrol yang menggunakan model pembelajaran konvensional. Namun penelitian tersebut dilakukan pada Mata Pelajaran IPA. Penelitian serupa juga telah dilakukan oleh Pratiwi (2016) di SMP Negeri 1 Grobogan. Hasil dari penelitian ini adalah PBL dapat meningkatkan pemahaman konseptual siswa dalam pokok bahasan Segitiga dan Segiempat.

Moffit (Rusman, 2010: 241) mengemukakan bahwa PBL adalah suatu model pembelajaran 
yang menggunakan masalah nyata (fakta) sebagai suatu konteks bagi siswa untuk belajar tentang berpikir kritis dan keterampilan dalam pemecahan masalah serta untuk memperoleh pengetahuan konsep dari materi pelajaran. PBL mengajarkan siswa bahwa permasalahan adalah sebagai pijakan awal dalam belajar (Wena, 2012: 91), sehingga siswa dapat menyusun pengetahuannya sendiri (Arends, 2008: 41). Melalui model PBL, siswa melakukan pembelajaran berdasarkan masalah sehingga siswa terbiasa dengan masalah dan penyelesaiannya.Dengan kata lain, siswa dapat membangun pengetahuannya sendiri.

Sintaks model PBL menurut Sugiyanto (2010) adalah: 1) orientasi peserta didik, 2) mengorganisasi peserta didik, 3) membimbing penyelidikan individu dan kelompok, 4) mengembangkan dan menyajikan hasil karya, 5) menganalisa dan mengevalusai proses pemecahan masalah.

Penelitian lain dengan model pembelajaran Discovery Learning (DL) juga mengungkapkan bahwa model tersebut dapat meningkatkan pemahaman konsep siswa. Contohnya adalah penelitian yang dilakukan oleh Suwarsi dkk (2018) di SMP N 9 Semarang. Dalam penelitian tersebut telah terbukti bahwa model pembelajaran DL berbantuan LKS dengan tema keluarga dapat meningkatkan pemahaman siswa. Penelitian serupa juga telah dilakukan oleh Vivi dkk (2018) pada materi pertidaksamaan eksponensial. Penelitian tersebut mendapat kesimpulan bahwa model DL dapat meningkatkan pemahaman konseptual siswa.

Menurut Sani (2014: 64) DL adalah suatu pembelajaran yang dilakukan bila materi pembelajaran tidak disajikan langsung dalam bentuk akhirnya, tetapi siswa mengkrontuksi sendiri. Sani (2014: 97) mengungkapkan bahwa discovery yaitu menemukan konsep melalui serangkaian data atau informasi yang diperoleh dari pengamatan atau eksperimen. Bruner (dalam Trianto: 2009) menyarankan agar siswa belajar dengan cara berpartisipasi langsung secara aktif dengan konsep dan prinsip materi yang dipelajari, memperoleh pengalaman dalam pembelajaran dan melakukan eksperimen untuk menemukan prinsip-prinsip itu sendiri. Adapun sintaks model pembelajaran DL antara lain: 1) pemberian rangsangan, 2) identifikasi masalah, 3) pengumpulan data, 4) pengolahan data, 5) pembuktian, 6) penarikan kesimpulan.

Berdasarkan penelitian-penelitian yang telah dilakukan sebelumnya, maka peneliti akan membandingkan model pembelajaran PBL dan DL terhadap pemahaman konseptual siswa. Melalui penerapan PBL dan DL, siswa dapat lebih aktif dalam mengeksplorasi pengetahuan yang dimiliki sehingga dapat meningkatkan pemahaman konseptualnya. Model pembelajaran PBL dan DL dinilai memicu siswa untuk aktif dalam dalam penyelidikan dan proses pemecahan masalah dalam pembelajaran.

Model pembelajaran PBL dipandang sebagai sebuah pembelajaran yang memiliki banyak keunggulan. Salah satu keunggulan tersebut adalah Model PBL mampu mengembangkan motivasi belajar siswa. Sedangkan Kurniasih \& Sani (2014: 66-67) juga mengemukakan salah satu kelebihan dari model DL adalah menimbulkan rasa senang pada siswa, karena tumbuhnya rasa penasaran dalam 
menyelidiki dan berhasil yang diharapkan dapat menimbulkan motivasi siswa. Kedua model tersebut dapat meningkatkan motivasi siswa.

Suyadi (2013: 143) mengungkapkan salah satu kelemahaman PBL adalah ketika peserta didik tidak memiliki niat yang tinggi atau keprcayaan diri bahwa dirinya mampu menyelesaikan masalah yang dipelajari, maka mereka cenderung enggan untuk mencoba, sedangkan menurut Westwood (Sani, 2014: 98) pada model DL Guru harus menjadi motivator bagi siswa agar siswa termotivasi dalam melakukan penyelidikan.

Sardiman (2006: 73) menjelaskan motivasi merupakan perubahan energi dalam diri seseorang yang ditandai dengan munculnya feeling dan didahului dengan tanggapan terhadap adanya tujuan. Peranannya yang khas adalah dalam hal penumbuhan gairah, merasa senang dan semangat untuk belajar. Martinis (2007: 219) juga berpendapat bahwa motivasi belajar merupakan daya penggerak psikis dari dalam diri seseorang untuk dapat melakukan kegiatan belajar dan menambah ketrampilan, pengalaman.

Agus Suprijono (2009: 163) menjelaskan motivasi belajar adalah proses yang memberi semangat belajar, arah, dan kegigihan perilaku. Artinya, perilaku yang termotivasi adalah perilaku yang penuh energi, terarah dan bertahan lama. Oemar Hamalik (2004: 173) menjelaskan motivasi dapat berupa dorongan-dorongan dasar atau internal dan intensif diluar individu atau hadiah. Motivasi adalah proses membangkitkan, mempertahankan, dan mengontrol minat-minat.

Adanya fakta bahwa pemahaman konseptual siswa di Indonesia masih tergolong rendah, model PBL dan DL dapat meningkatkan pemahaman konseptual siswa, dan motivasi berperan penting dalam keberhasilan model, maka peneliti ingin meneliti ada atau tidaknya perbedaan kedua model tersebut terhadap pemahaman konseptual siswa ditinjau dari motivasi siswa. Peneliti juga ingin meneliti model pembelajaran manakah yang menghasilkan pemahaman konseptual yang lebih baik diantara model PBL dan DL dan tingkat motivasi manakah yang lebih baik untuk tiap model untuk memberi gambaran bagaimana menerapkan model pembelajaran PBL dan DL dalam pembelajaran matematika yang diharapkan dapat menginspirasi guru untuk menerapkan model tersebut.

Penerapan model PBL dan DL dalam penelitian ini diharapkan dapat menjadi sarana untuk mewujudkan suatu proses pembelajaran yang berorientasi pada pemahaman konseptual siswa bukan hanya hasil belajarnya saja ditinjau dari tingkat motivasi belajar siswa. Penelitian ini dilakukan dalam pembelajaran matematika di SMA pada materi barisan. Dengan demikian, diharapkan dapat menginspirasi guru untuk menerapkan model PBL maupun DL ke dalam pembelajaran matematika pada materi lain dan bahkan dalam pembelajaran lainnya. Selain itu, hasil penelitian ini diharapkan dapat dijadikan dasar bahan kajian untuk penelitian pendidikan lainnya.

\section{METODE}

Penelitian ini adalah penelitian kuantitatif dengan jenis quasi experimental research atau eksperimen semu. Menurut Budiyono (2003: 79-83) penelitian dapat dikatakan penelitian 
eksperimental semu jika tidak dapat memungkinkan bagi seorang peneliti untuk mengendalikan dan memanipulasi semua variable yang relevan.

Penelitian ini bertujuan untuk mengetahui ada atau tidaknya perbedaan antara variable terikat dan variable bebas, dimana variable terikat yaitu pemahaman konsep siswa sedangkan variable bebasnya adalah model pembelajaran PBL dan DL. Penelitian ini memperhatikan satu variable atributif yaitu motivasi belajar.

Penelitian ini dilaksanakan di Sekolah SMA Negeri 1 Bringin pada Semester II Tahun Ajaran 2018/2019. Penelitian ini dimulai sejak Desember 2018 - Agustus 2019 dengan menggunakan subyek penelitiannya adalah siswa kelas XI dengan jumlah sampel sebanyak 57 yang dibagi menjadi 2 kelas yaitu kelas XI MIPA 2 dan XI MIPA 3. Kelas XI MIPA 2 atau kelas eksperimen 1 yang berjumlah 29 orang diberi model PBL sedangkan kelas XI MIPA 3 atau kelas eskperimen 2 yang berjumlah 28 orang diberi model DL.

Menurut Budiyono (2003: 93) desain penelitian yang digunakan adalah randomaized control group pretest-posttest deisgn dimana desain ini memperlihatkan kemampuan awal siswa dengan membandingkan kemampuan awal kelas ekperimen dan kelas pembanding, selanjutnya dilakukan uji beda rerata untuk mengetahui ada atau tidaknya perbedaan rata-rata keduanya setelah mendapat perlakuan. Desain penelitian yang digunakan oleh penelitian digambarkan pada Tabel 1.

\section{Tabel 1.}

Desain Penelitian

\begin{tabular}{|l|c|c|c|}
\hline Kelas & Pretest & Perlakuan & Postest \\
\hline Kelas Eksperimen (R) & $\mathrm{T}_{1}$ & $\mathrm{X}_{1}$ & $\mathrm{~T}_{2}$ \\
\hline Kelas Pembanding (R) & $\mathrm{T}_{1}$ & $\mathrm{X}_{2}$ & $\mathrm{~T}_{2}$ \\
\hline
\end{tabular}

Keterangan :

$\mathrm{R}$ : Kelas eksperimen dan pembanding yang diambil secara random

$\mathrm{T} 1$ : Kondisi awal kelas eksperimen dan pembanding sebelum diberikan perlakuan

$\mathrm{X} 1$ : Perlakuan pembelajaran dengan model pembelajaran PBL

X2 : Perlakuan pembelajaran dengan model pembelajaran DL

T2 : Kondisi akhir kelas eksperimen dan pembanding setelah diberikan perlakuan

Teknik pengumpulan data menggunakan metode tes yang berupa pretes untuk kedua kelas sebelum siswa mendapatkan perlakuan yang digunakan sebagai nilai kemampuan awal siswa, metode observasi yang digunakan untuk menilai keterlaksanaan penerapan model pembelajaran PBL dan DL, serta motivasi belajar siswa. Selain itu, penelitian ini juga menggunakan metode tes berupa posttes untuk mengukur pemahaman konseptual siswa setelah diberikan perlakuan dan metode angket motivasi belajar untuk mengukur tingkat motivasi belajar tiap siswa.

Instrumen yang digunakan dalam penelitian ini adalah instrumen tes pretest dan posttest yang mana masing-masing terdiri dari 5 soal uraian. Instrumen tersebut telah divalidasi oleh dosen pendidikan matematika dan guru matematika. Adapun instrumen lain yang digunakan adalah angket motivasi belajar yang telah diuji validitas dan reliabilitasnya. 
Uji analisis data dilakukan 2 kali yaitu uji keseimbangan kemampuan awal dan uji hipotesis. Kedua uji tersebut sama-sama menggunakan uji beda rerata. Guna menentukan uji beda rerata yang digunakan (parametik/ non-parametik) maka perlu dilakukan uji normalitas. Untuk uji normalitas yang terpenuhi maka menggunakan uji beda rerata parametik, Independent Samples T-Test untuk uji keseimbangan kemampuan awal dan anava 2 jalan untuk uji hipotesis.

Terdapat dua jenis Independent Samples T-Test, oleh karena itu dilakukan uji homogenitas. Jika uji homogenitas terpenuhi maka Independent Samples T-Test yang digunakan adalah Equal Variances Assumed, tetapi jika tidak terpenuhi maka menggunakan Equal Variances not Assumed. Jika uji normalitas tidak terpenuhi maka uji beda rerata yang digunakan adalah non-parametik yaitu uji MannWhitney untuk uji keseimbangan kemampuan awal dan untuk uji hipotesis menggunakan uji MannWhitney jika terdiri dari 2 kelompok data independen dan uji Kruskal Wallis untuk 3 kelompok data independen.

\section{HASIL}

Pengambilan data yang dilakukan pada bulan Februari sampai Maret 2019 di SMA Negeri 1 Bringin mendapat data berupa pemahaman konsep awal siswa sebelum diberi perlakuan yang dapat dilihat dari hasil tes barisan aritmatika, proses pembelajaran dengan menggunakan model pembelajaran PBL pada kelas eksperimen 1 dan model pembelajaran DL pada kelas eksperimen 2, hasil observasi guru dan siswa selama proses pembelajaran, hasil pemahaman konsep siswa setelah diberi perlakuan serta hasil pengisian angket motivasi belajar siswa. Analisis dari data kemampuan awal siswa sebelum diberi perlakuan akan dideskripsikan sebagai berikut.

Data perolehan kemampuan awal untuk setiap kelompok sampel dapat dilihat pada Tabel 2. Hasil analisis data kemampuan awal tampak bahwakelas eksperimen 1 yang berjumlah 29 siswamemiliki rata-rata (69.17) dengan nilai standar deviasi sebesar (20.67) sedangkan kelas eksperimen 2 mendapat rata-rata yang lebih tinggi dibanding kelas eksperimen 1 yaitu (77.00) dengan standar deviasi yang tidak jauh berbeda yaitu (21.07).Namun jika dilihat dari nilai minimum dan maksimum, kedua kelas eksperimen memiliki nilai minimum dan maksimum yang sama yaitu (24.00) dan (100.00).

\section{Tabel 2.}

Data Kemampuan Awal

\begin{tabular}{|l|l|l|l|}
\hline & \multicolumn{1}{|c|}{ Max } & \multicolumn{1}{c|}{ Mean } & \multicolumn{1}{c|}{ Std. Dev } \\
\hline Eksperimen 1 & 100 & 69.17 & 20.67 \\
\hline Eksperimen 2 & 100 & 77.00 & 21.08 \\
\hline
\end{tabular}

Untuk menguji keseimbangan kemampuan awal dari kedua kelompok eksperimen, maka dilakukan uji beda rerata. Diperlukan uji normalitas untuk menentukan uji beda rerata yang akan digunakan. Uji normalitas yang digunakan yaitu Uji Shapiro-Wilk karena sampel berjumlah 29 dan 28 saja. Hasil uji normalitas dapat dilihat pada Tabel 3. Di mana kelas eksperimen 1 memiliki signifikan 0.153 atau lebih dari 0.05 sedangkan kelas eksperimen 2 memiliki signifikan 0.008 maka kurang dari 
0.05. Hal ini berarti kelas eksperimen 2 tidak berasal dari populasi yang berdistribusi normal.

Tabel 3.

Uji Normalitas Munggunakan Shapiro-Wilk

\begin{tabular}{|l|r|r|r|}
\hline Kelas & Statistic & \multicolumn{1}{|c|}{ df } & \multicolumn{1}{c|}{ Sig. } \\
\hline Eksperimen_1 & .947 & 29 & .153 \\
\hline Eksperimen_2 & .893 & 28 & .008 \\
\hline
\end{tabular}

Dikarenakan ada salah satu kelas eksperimen yang tidak berasal dari populasi yang berdistribusi normal, uji beda rerata yang digunakan adalah uji non parametik yaitu Uji Mann-Whitney. Berdasarkan Uji Mann-Whitney pada tabel 5, diketahui bahwa nilai signifikan sebesar 0,109 (lebih dari 0,05$)$. Oleh karena itu dapat disimpulkan bahwa kelompok eksperimen secara signifikan memiliki kemampuan awal yang seimbang.

Pelaksanaan kegiatan pembelajaran di kelas PBL maupun DL sudah direncanakan sesuai dengan teori yang ada. Kegiatan pembelajaran juga sudah dilakukan secara optimal sesuai dengan RPP yang telah disusun sebelumnya. Rekapitulasi hasil observasi dari keterlaksanaan kedua model dapat dilihat pada Tabel 4.

Tabel 4..

Hasil Observasi Guru

\begin{tabular}{|l|c|}
\hline \multicolumn{1}{|c|}{ Aspek yang diamati } & Persentase \\
\cline { 2 - 2 } & PBL \\
\hline Kesesuaian RPP dengan Kurikulum 2013 & 85 \\
\hline Kesesuaian pembelajaran dengan model pembelajaran & 91 \\
\hline Penguasaan kelas & 81 \\
\hline Penguasaan materi & 88 \\
\hline Sikap, penampilan, tulisan dan tutur kata & 90 \\
\hline
\end{tabular}

\section{Tabel 5.}

Uji Beda Rerata menggunakan Uji Mann-Whitney

\begin{tabular}{|l|l|}
\hline \multicolumn{1}{|c|}{ Uji } & Pretest \\
\hline Mann-Whitney U & 306.000 \\
\hline Wilcoxon W & 741.000 \\
\hline Z & -1.602 \\
\hline Asymp. Sig. (2-tailed) & .109 \\
\hline
\end{tabular}

Analisis Deskriptif Pemahaman Konsep Siswa Setelah Perlakuan (Kondisi Akhir) diperoleh data nilai akhir 29 siswa dari kelas eksperimen 1 dan 28 siswa dari kelas eksperimen 2 adalah nilai posttest. Adapun deskripsi nilai posttest yang diperoleh kedua kelompok sampel dapat dilihat pada Tabel 6.

\section{Tabel 6.}

Pemahaman Konsep Siswa Setelah Perlakuan

\begin{tabular}{|l|r|r|r|r|r|}
\hline & \multicolumn{1}{|c|}{ N } & \multicolumn{1}{c|}{ Max } & \multicolumn{1}{c|}{ Min } & \multicolumn{1}{c|}{ Mean } & \multicolumn{1}{c|}{ Std. Dev } \\
\hline Eksperimen_1 & 29 & 100 & 20 & 59.31 & 23.521 \\
\hline Eksperimen_2 & 28 & 100 & 54 & 78.50 & 14.326 \\
\hline
\end{tabular}


Dilihat dari data kemampuan akhir siswa, kelas eksperimen 2 dengan 28 siswa yang menggunakan model DL memiliki rata-rata yang lebih baik dari pada kelas eksperimen 1 dengan 29 siswa yang menggunakan model PBL. Kelas eksperimen 2 menghasilkan rata-rata 78.50 sedangkan kelas eksperimen 1 menghasilkan rata-rata 59.31. Ditilik dari nilai minimum yang diperoleh kedua kelas eksperimen, kelas eksperimen 2 menghasilkan nilai minimum 54 yang artinya lebih tinggi dari pada kelas eksperimen 1 dengan nilai minimum 20 meskipun nilai maksimum yang diperoleh kedua kelas eksperimen sama yaitu 100 .

Penelitian ini tidak hanya meneliti mengenai pemahaman konsep siswa namun juga ditinjau dari motivasi belajar siswa. Rekapan hasil pemahaman konsep siswa yang sudah dikelompokkan berdasarkan tingkat motivasi belajar tinggi, sedang dan rendah dapat dilihat pada Tabel 7 .

\section{Tabel 7.}

Nilai Rata-Rata Kondisi Akhir berdasarkan Tingkat Motivasi Belajar

\begin{tabular}{|l|c|c|c|c|}
\hline \multirow{2}{*}{ Kelas } & \multicolumn{3}{|c|}{ Tingkat Motivasi } & \multirow{2}{*}{$\begin{array}{c}\text { Rata- } \\
\text { Rata }\end{array}$} \\
\cline { 2 - 4 } & Tinggi & Sedang & Rendah & 59.31 \\
\hline Eksperimen 1 & 81.43 & 61.86 & 35.50 & 78.50 \\
\hline Eksperimen 2 & 87.00 & 78.91 & 70.44 & \\
\hline Rata-Rata & 84.40 & 69.36 & 54.00 & \\
\hline
\end{tabular}

Berdasarkan data yang diperoleh, siswa dengan tingkat motivasi belajar tinggi, sedang dan rendah yang dikenai model DL masing-masing menghasilkan nilai rata-rata yang lebih tinggi dari pada yang dikenai model PBL. Adapun nilai rata-rata siswa dengan tingkat motivasi belajar tinggi adalah 84.40 yang artinya lebih tinggi dibandingkan siswa dengan tingkat motivasi belajar sedang dan rendah. Nilai rata-rata yang dihasilkan siswa dengan tingkat motivasi belajar sedang yaitu 69.36 berarti lebih baik dari pada siswa dengan tingkat motivasi belajar rendah yang memperoleh rata-rata 54.00.

Analisis inferensial pada kondisi akhir dengan nilai posttestakan menggunakan uji statistik. Untuk menentukan uji yang akan digunakan maka perlu dilakukan uji normalitas. Hasil uji normalitas data kemampuan akhir dapat dilihat pada Tabel 8 dan 9 yang meliputi uji normalitas berdasarkan tingkat motivasi belajar dan uji normalitas berdasarkan kelas model pembelajaran.

\section{Tabel 8.}

Uji Normalitas

\begin{tabular}{|l|l|l|l|}
\hline \multirow{2}{*}{ MOTIVASI } & \multicolumn{3}{|l|}{ Shapiro-Wilk } \\
\cline { 2 - 4 } & Statistic & df & Sig. \\
\hline TINGGI & .836 & 15 & .011 \\
\hline SEDANG & .958 & 25 & .385 \\
\hline RENDAH & .947 & 17 & .405 \\
\hline
\end{tabular}




\section{Tabel 9.}

Uji Normalitas Berdasarkan Kelas Model Pembelajaran

\begin{tabular}{|c|l|c|c|}
\hline \multirow{2}{*}{ KELAS } & \multicolumn{3}{|c|}{ Shapiro-Wilk } \\
\cline { 2 - 4 } & Statistic & df & Sig. \\
\hline Eksperimen_1 & .957 & 29 & .271 \\
\hline Eksperimen_2 & .910 & 28 & .020 \\
\hline
\end{tabular}

Hasil uji normalitas nilai posttest berdasarkan tingkat motivasi belajar dan kelas model pembelaajaran mendapatkan nilai signifikan $0.011 ; 0.385 ; 0.405 ; 0.271$ dan 0.020 . Nilai signifikan yang diperoleh tingkat motivasi tinggi dan kelas eksperimen 2 kurang dari 0.05 yang artinya tidak berasal dari populasi yang berdistribusi normal. Melihat karakteristik data dengan beberapa kelompok sampel tidak berasal dari populasi yang berdistribusi normal, maka uji yang digunakan adalah uji non parametik

Analisis uji beda rerata kondisi akhir menggunakan uji non parametik yang digunakan adalah Uji Mann-Whitney dan Uji Kruskal Walls. Uji beda rerata dilakukan 7 kali yaitu antar kedua model pembelajaran, antar ketiga tingkat motivasi belajar, antar model pada kelas eksperimen 1 (PBL) terhadap ketiga tingkat motivasi belajar, antar model pada kelas eksperimen 2 (DL) terhadap ketiga tingkat motivasi belajar, tingkat motivasi belajar tinggi terhadap kedua model pembelajaran, tingkat motivasi belajar sedang terhadap kedua model pembelajaran dan tingkat motivasi belajar rendah terhadap kedua model pembelajaran.

Tabel 9.

Uji Beda Rerata antar Kedua Model Pembelajaran

\begin{tabular}{|c|c|}
\hline & Posttest \\
\hline Mann-Whitney U & 217.500 \\
\hline Wilcoxon W & 652.500 \\
\hline Z & -3.019 \\
\hline Asymp. Sig. (2-tailed) & .003 \\
\hline
\end{tabular}

Tabel 10.

Uji Beda Rerata antar Ketiga Tingkat Motivasi Belajar

\begin{tabular}{|l|l|}
\hline & Posttest \\
\hline Chi-Square & 15.752 \\
\hline Df & 2 \\
\hline Asymp. Sig. & .000 \\
\hline
\end{tabular}

Tabel 11.

Uji Beda Rerata Model PBL terhadap Ketiga Tingkat Motivasi

\begin{tabular}{|l|l|}
\hline & Posttest \\
\hline Chi-Square & 14.655 \\
\hline
\end{tabular}




\begin{tabular}{|l|l|}
\hline Df & 2 \\
\hline Asymp. Sig. & .001 \\
\hline
\end{tabular}

Tabel 12.

Uji Beda Rerata Model DL terhadap Ketiga Tingkat Motivasi

\begin{tabular}{|l|l|}
\hline & Posttest \\
\hline Chi-Square & 5.808 \\
\hline Df & 2 \\
\hline Asymp. Sig. & .055 \\
\hline
\end{tabular}

Tabel 13.

Uji Beda Rerata Tingkat Motivasi Belajar Rendah terhadap Kedua Model Pembelajaran

\begin{tabular}{|l|c|}
\hline & Posttest \\
\hline Mann-Whitney U & .500 \\
\hline Wilcoxon W & 36.500 \\
\hline Z & -3.446 \\
\hline Asymp. Sig. (2-tailed) & .001 \\
\hline Exact Sig. [2*(1-tailed Sig.)] & .000 \\
\hline
\end{tabular}

\section{Tabel 14.}

Uji Beda Rerata Tingkat Motivasi Belajar Sedang terhadap Kedua Model Pembelajaran

\begin{tabular}{|l|l|}
\hline & POSTEST \\
\hline Mann-Whitney U & 44.500 \\
\hline Wilcoxon W & 149.500 \\
\hline Z & -1.792 \\
\hline Asymp. Sig. (2-tailed) & .073 \\
\hline Exact Sig. [2*(1-tailed Sig.)] & $.075^{\mathrm{b}}$ \\
\hline
\end{tabular}

\section{Tabel 15.}

Uji Beda Rerata Tingkat Motivasi Belajar Tinggi terhadap Kedua Model Pembelajaran

\begin{tabular}{|l|l|}
\hline & Posttest \\
\hline Mann-Whitney U & 26.000 \\
\hline Wilcoxon W & 54.000 \\
\hline Z & -.235 \\
\hline Asymp. Sig. (2-tailed) & .814 \\
\hline Exact Sig. [2*(1-tailed Sig.)] & $.867^{\text {b }}$ \\
\hline
\end{tabular}

Hasil uji beda rerata pada Tabel 9 menunjukkan bahwa terdapat perbedaan pemahaman konsep yang dihasilkan oleh model pembelajaran PBL dan DL. DL secara signifikan menghasilkan pemahaman konseptual yang lebih baik dibandingkan PBL. Hal ini dimungkinkan karena pada model DL siswa mengkonstruksi sendiri pengetahuan yang ia dapat dengan melakukan percobaan secara langsung jadi siswa lebih memahami konsep. Adapun hasil uji beda rerata pada Tabel 10 menunjukkan tingkat motivasi belajar tinggi, sedang dan rendah juga menghasilkan pemahaman 
konsep yang tidak setara di mana siswa dengan tingkat motivasi belajar tinggi secara signifikan menghasilkan pemahaman konseptual yang lebih baik dibanding sedang dan rendah, sedangkan siswa dengan tingkat motivasi belajar sedang secara signifikan menghasilkan pemahaman konseptual yang lebih baik dibanding rendah karena semakin tinggi tingkat motivasi siswa, siswa tersebut akan lebih giat dalam mengikuti pembelajaran baik dalam pemecahan masalah atau pun melakukan suatu percobaan.

Tabel 11 menunjukkan bahwa terdapat perbedaan yang signifikan antara ketiga tingkat motivasi pada kelas PBL. Siswa dengan tingkat motivasi tinggi secara signifikan menghasilkan pemahaman konseptual yang lebih baik dibanding sedang dan rendah, sedangkan siswa dengan tingkat motivasi belajar sedang secara signifikan menghasilkan pemahaman konseptual yang lebih baik dibanding rendah. Hal ini dimungkinkan karena semakin rendahnya motivasi belajar siswa, semakin enggan pula siswa tersebut memecahkan suatu permasalahan padahal PBL adalah suatu model di mana permasalahan sehari-hari dijadikan batu pijakan pertama dalam suatu pembelajaran. Dilihat dari tabel 12, ternyata pemahaman konseptual yang dihasilkan oleh siswa dengan tingkat motivasi belajar tinggi, sedang dan rendah seimbang karena adanya peran langsung seluruh siswa kelas DL dalam melakukan suatu percobaan maka tingkat motivasi belajar tinggi, sedang dan rendah sama-sama menemukan sendiri konsep yang sedang diajarkan maka dimungkinkan akan lebih memahami konsep tersebut.

Menurut tabel 13 dan 14, tidak terdapat perbedaan yang signifikan antara model PBL dan DL pada tingkat motivasi belajar tinggi. Dimungkinkan motivasi siswa dengan tingkat motivasi tinggi dan sedang lebih giat mengikuti seluruh proses pembelajaran. Namaun pada tabel 15, terdapat perbedaan yang signifikan antara model PBL dan DL pada tingkat motivasi belajar rendah di mana dilihat dari rata-ratanya DL menghasilkan pemahaman konseptual yang lebih baik dibanding PBL karena siswa dengan tingkat motivasi rendah akan merasa malas dan enggan untuk melakukan pemecahan masalah namun akan merasa lebih tertantang dengan percobaan-percobaan yang akan dilakukan.

\section{KESIMPULAN}

Berdasarkan hasil penelitian maka dapat disimpulkan bahwa; (1) DL secara signifikan menghasilkan pemahaman konseptual yang lebih baik dibanding PBL; (2) Tingkat motivasi belajar tinggi secara signifikan menghasilkan pemahaman konseptual yang lebih baik dibanding tingkat motivasi belajar sedang dan rendah sedangkan tingkat motivasi belajar sedang secara signifikan menghasilkan pemahaman konseptual yang lebih baik disbanding tingkat motivasi belajar rendah; (3) terdapat interaksi antara model pembelajaran PBL dengan motivasi belajar terhadap pemahaman konseptual siswa yaitu tingkat motivasi belajar tinggi secara signifikan menghasilkan pemahaman konseptual yang lebih baik dari pada tingkat motivasi sedang dan rendah sedangkan motivasi belajar sedang secara signifikan menghasilkan pemahaman konseptual yang lebih baik dibanding siswa dengan motivasi belajar rendah, adapun pada model pembelajaran DL pemahaman konseptual yang 
dihasilkan siswa dengan tingkat motivasi tinggi, sedang dan rendah sama, pada tingkat motivasi belajar tinggi dan sedang tidak terdapat perbedaan yang signifikan antara model PBL dan DL, sedangkan siswa dengan tingkat motivasi rendah pada kelas DL secara signifikan mendapatkan pemahaman konseptual yang lebih baik dari pada siswa dengan tingkat motivasi rendah pada kelas PBL.

Berdasarkan hasil tersebut, maka disarankan bagi guru untuk lebih berorientasi pada proses dalam langkah pembelajaran. Selain itu, disarankan juga untuk dapat menciptakan situasi pembelajaran yang dapat menumbuhkan motivasi belajar siswa agar terciptanya pemahaman konsep yang lebih baik. Adapun bagi peneliti lain yang hendak membandingkan pemahaman konsep dari sampel dengan tingkat motivasi belajar yang berbeda, maka disarankan untuk melakukan penelitian dengan memilih medel pembelajaran yang lain sehingga diharapkan mendapat hasil yang berbeda. Selain itu, disarankan pula bagi penelitian yang akan membandingkan model PBL dan DL, tidak sekedar melihat dari segi tingkat motivasi belajarnya.

\section{DAFTAR PUSTAKA}

Arends, R. (2008). Learning to Teach. Jogjakarta: Pustaka Pelajar.

Aunurrahman. (2012). Belajar dan Pembelajaran. Bandung: Alfabeta.

Hamalik, O. (2004). Proses Belajar Mengajar. Jakarta: Bumi Aksara.

Kementrian Pendidikan dan Kebudayaan. (2014). Nomor 58 tentang Kurikulum SMP.

$\begin{array}{lllll}\text { Litbang } & \text { Kemendikbud. (2015). Survey } & \text { Internasional }\end{array}$

http://litbang.kemendikbud.go.id/index.php/survei_internasional-timss/tentang timss

Martinis, Y. (2007). Profesionalisasi Guru dan Implementasi KTSP. Jakarta: Gaung Persada Press.

Niswatuzzahro, V., Fakhriyah, V., \& Rahayu, R. (2018). Penerapan Model Discovery Learning Berbantuan Media Audio Visual untuk Meningkatkan Literasi Sains Siswa Kelas 5 SD. Scholaria: Jurnal Pendidikan dan Kebudayaan, Vol. 08 (No. 03), 273-284.

Pratiwi, H. D. (2016). Peningkatan Pemahaman Konsep Matematika Pada Pokok Bahasan Segiempat dan Segitiga Melalui Metode Problem Based Learning. Surakarta: Universitas Muhammadiyah Surakarta.

Rusman. (2010). Model Model Pembelajaran. Bandung: Rajawali.

Sani, A. R. (2014). Pembelajaran Saintifik untuk Kurikulum 2013. Jakarta: Bumi Aksara.

Sardiman. (2008). Interaksi dan Motivasi Belajar Mengajar. Jakarta: Raja Garfindo Persabda.

Soedjadi. (2000). Kiat Pendidikan Matematika di Indonesia. Bandung: Dirjen Dikti.

Sugiyanto. (2010). Model-Model Pembelajaran Inovativ. Surakarta: Yuma.

Suherman, E. (2003). Strategi Pembelajaran Matematika Kontemporer. Bandung: UPI.

Suprijono, A. (2009). Cooperative Learning. Yogyakarta: Pustaka Pelajar. 
Suriana. (2016). Penerapan Model Problem Based Learning (PBL) Berbasis Eksperimen Untuk Meningkatkan Pemahaman Konsep Usaha dan Energi Ditinjau dari Gaya Berpikir Siswa di MAN Rukoh Banda Aceh. Jurnal Pendidikan Sains Indonesia, Vol.04 (No.02), 127-139.

Suwarsi. (2018). Meningkatkan Pemahaman Konsep Matematis dan Kerja Sama Siswa Kelas VIIIF melalui DL Berbantuan LKS Bertema. PRISMA, 40-48. Semarang: Universitas Negeri Semarang.

Suyadi. (2013). Strategi Pembelajaran Pendidikan Karakter. Bandung: PT Remaja Rosdakarya Offset.

Trianto. (2009). Mendesain Model Pembelajaran Inovatif Progresif. Surabaya: Kencana.

Wena, M. (2012). Strategi Pembelajaran Inovativ Kontemporer. Jakarta: Bumi Aksara. 